QUININE TREATMENT OF MALARIA.

To the Editor of THE LANCET.

SIR,-Will you allow me to rectify an omission in my paper on the Treatment of Malaria by Quinine, which appeared in your issue of Feb. 12th? The last sentence-"This aspect of the question ....."-was borrowed without acknowledgment from a paper by Lieutenant-Colonel J. W. Cornwall, I.M.S., read before the Indian Science Congress of 1919, and is contained in the proceedings of that Congress published in a special number of the Indian Journal of Medical Research, p. 88. I much regret the omission.

I am, Sir, yours faithfully,

Westward Ho! Feb. 16th, 1921.

P. HEHIR.

\section{dettediral 趣etos.}

UNIVERSITY OF CAMBRIDGE : DIPLOMA IN MEDICAT RADIOLOGY AND ELECTROLOGY.-The Special Board for Medicine, on the recommendation of the Committee on Medical Radiology and Electrology, has approved the grant of the Diploma in Medical Radiology and Electrology to Drs. J. E. A. Lynham, A. E. H. Pinch, W. J. Turrell, A. E. Barclay, and F. Hernaman-Johnson.

UNIVERSITY OF BRISTOL.-At examinations held recently the following candidates were successful :-

EXAMINATION FOR DEGREE OF M.D.

Adolph Reeve Heber.

Final Examination for Degrefes of M.B., Ch.B.

Part II. (completing examination).-William Harris Royal and Majorie Wadsworth (first-elass honours).

Part I. only (including Forensic Medicine and Toxicology).William Austin Jackman and Percy Phillips.

Part I. only.-Phyllis Beames, Macdonald Critchley, John Rukin Duerden, Winifred Grace Nott, John Augustin Prichard, William Kenneth Armstrong Richards, and Victoria Sophia Tryon

Final Examination for Diploma in Dental Strgery.

Norman Henry Bodenham.

Examination for Diploma in Public Heatth.

Part II. (completing examination).-Frederick Vaudrey Cant,

Allan Dumbreck Fraser, and Geoffrey Commeline Williams.

Royal College of Physicians of Edinburgh.The Morison lectures will be delivered by Sir Frederick Mott, F.R.S., in the Hall of the College, 9, Queen-street, Edinburgh, at 5 P.M., on March 7th, 9th, and 11. The subject will be the Psychopathology of Puberty and Adolescence, and each lecture will be illustrated by drawings and lantern slide demonstrations.

London Hospital Medical College (University of London).-A course of 12 lecture-demonstrations on Gonorrhœea will be given by Mr. E. R. Townley Clarkson and Dr. A. Malcolm Simpson (chief assistant to the genitourinary department of the hospital), on Tuesdays and Thursdays (men), and Wednesdays and Fridays (women), at 4.30 P.M. The course is intended for senior students of the hospital and for medical practitioners, who are invited to attend.

MEDICAI Society of London.-A meeting will be held at 11, Chandos-street, Cavendish-square, London, W., on Monday, Feb. 28th, at 8.30 P.M. A discussion on the Chemical Estimation of Gastric F'unction will be introduced by Dr. J. H. Ryffel and Dr. J. A. Ryle. Dr. T. I. Bennett, Dr. R. L. M. Wallis, Mr. E. C. Dodds, Dr. G. Graham, Dr. C. Bolton, Dr. R. Hutchinson, and Dr. W. H. Willcox will be among the speakers.

ROYAL INSTITUTION.-On Saturday next, March 5th, at 3 o'clock, Sir Ernest Rutherford will deliver the first of a course of three lectures at the Royal Institution on Electricity and Matter, and on Thursday, March 10th, Dr. G. C. Simpson, director of the Meteorological Office, commences a course of two lectures on the Meteorology of the Antarctic. The Friday evening discourse on March 11th will be delivered by Dr.J. Freeman on Medical Idiosyncrasies.

INDUSTRIAL WELFARE CONFERENCE.-I'Le Industrial Welfare Society is arranging a conference to be held at the Mansion House on March 2nd. The Lord Mayor will preside, and the speakers will include the Duke of York, the Right Hon. F. Short, M.P., the Right Hon. H. A. L. Fisher, M.P., the Right Hon. J. R. Clynes, M.P., Alderman Sir Charles C. Wakefield, and Sir William H. Ellis, D.Sc.
Dr. O. K. Williamson, who was recently appointed to the Chair of Medicine at University College, Johannesburg. does not take up his new duties until February, 1922, and will not be leaving England before the end of the present year.

TUBERCULOSIS SOCIETY OF GREAT BRITAIN AND IRELAND-A meeting of this society will be held at the Margaret-street Hospital, London, W., on Monday, Feb. 28th, at 7.30 P.M., when Dr. W. Gordon will read a paper on Rainbearing Winds and Tuberculosis.

The Re-Education of The Disabled.-A lecture on this subject will be given by Captain J. Manclark Hollis, secretary to the Village Centres Council, on Wednesday, March 2nd, at 8 P.M., at the house of the Royal Society of Arts, John-street, Adelphi, London, W.C.

THE Royal Faculty of Physicians and Surgeons, Glasgow, has recently sustained a loss in the death of its secretary and librarian, Mr. Alexander Duncan, B.A., I.L.D. who died on Feb. 14th. Mr. Duncan, who had held his appointment for over 55 years, had an all-round knowledge of medical literature. He devoted much time to the preparation of a catalogue of the extensive medical library under his supervision and was the author of a serviceable history of the medical profession in the West of Scotland.

Royad Statistrad Societr.-The council will, in November, 1921, award the Frances Wood Memorial Prize, value $£ 30$, for the best investigation of any problem dealing with the economic or social conditions of the wageearning classes. The subject is to be chosen by the competitor and is to be treated on statistical lines. Essays must be sent, not later than July 1st next, to the Honorar Secretaries of the Royal Statistical 3ociety, '9, Adelphiterrace, London, W.C.2, from whom further information mav be obtained.

Tavistock Clinic for Functional Nerve Cases. The second of a course of five lectures on Analytical Psychology will be given by Dr. Maurice Nicoll on Monday, Feb. 28th, at 5.15 P.M. A course of ten lectures on Elementary Psychotherapy will be given by Dr. H. Crichton Miller on Fridays, at 5.15 P.M., beginning May 6th. The fees for each course are: medical practitioners, £2 $2 \mathrm{~s}$., medical students, $£ 1 \mathrm{ls}$., and tickets should be taken in advance from the honorary lecture secretary at the clinic, 51, Tavistock-square, London, W.C.1.

THE Institut Francais du Royaume Uni will be opened at 1-7, Cromwell-gardens, $S . W$. on Saturday next Feb. 26th, at 3 o'clock, under the presidency of the French Ambassador, the Comte de Saint Aulaire. The French Minister of Education, M. Léon Bérard, will represent his Government, and the English Board of Education and the London County Council will also be represented. Three delegates are expected from the Paris Municipal Council and from the University of Paris. Among the latter will be Mons. Appel, the Rector of the University, and Mons. Henr Bergson. The Rector of the University of Lille is also expected to be present, that University being the parent of the movement.

Federation of Medical and Allied Societies. A meeting of the Executive Council was held on Feb. 15th at 11, Chandos-street, London, W. Two letters from the Minister of Health were read stating his gratification at the work already accomplished by the Federation, and reaffirming his view that such a body should represent, not its own interests primarily, but the wider interests of the nation. The council then considered the new regulations drafted by the Secretary of State under Section 7 of the Dangerous Drugs Act, 1920. The Pharmaceutical Society of Great Britain pointed out that certain clauses of the Bill affecting its members were unworkable and that the time allowed for their consideration and the representation of views had been inadequate. Pending the receipt of the views of the constituent bodies in the Federation a letter had been sent by the council to the Under Secretary of State on Feb. 9th asking for an extension of the period provided for the representation of the views of interested bodies. The Under Secretary replied that he would gladly receive representations from the Federation, and hoped they would be made at an early date. A letter was also received on this mutter from Captain W. E. Elliot, M.P., secretary of the Medical Committee of the House of Commons. The interests of the insured person in connexion with the new medical record cards were further considered. Dr. H. J. Cardale, representing the Association of Panel Committees in the Federation, showed the cards and fully explained the method of using them. The meeting was of opinion that the principle of keeping such records could not be condemned, and that six months' trial of the actual cards issued would demonstrate their value or their faults. 